\title{
MATRIX OF RISK FACTORS FOR RAILWAY CONSTRUCTION PROJECTS
}

\author{
Jan Kowalski ${ }^{\boxplus}$, Marzena Lendo-Siwicka \\ Institute of Civil Engineering, Warsaw University of Life Sciences - SGGW, Warsaw, Poland
}

\begin{abstract}
The article presents main assumptions of an original method for scheduling railway investments in Poland, taking into account the risk factors during their implementation. The risk factors were identified by the authors during extensive research and analysis. Based on the proposed method, a future user will be able to determine the most likely cost and duration of a planned investment. The article also presents the implementation of the method in a real investment process (construction project) in terms of its implementation time. When designing the method, it was assumed that the method which is not complicated to implement and is supported by an appropriate computational program will motivate teams planning railway projects to implement them in real implementation processes and increase the credibility of their schedules.
\end{abstract}

Key words: threat identification, risk, railway investments, planning of construction works, risk matrix

\section{INTRODUCTION}

As Anysz (2017) writes, the field of the project management science aimed at reduction of the impact of risks of non-compliant implementation is the interdisciplinary science of risk management. Połoński (2015) defines risk management as qualitative and quantitative risk analyses. Skorupka (2007) interprets risk as a commonly known term often used in various areas of human activity. For this reason, in practice, the concept of risk is understood and defined in various ways (Willett, 1951; Pfeffer, 1956; Regan, 2003). "Economists, who usually focus only on financial aspects, understand risk differently than engineers, who refer the problem of risk to disruptions in the operation of machines or production processes. Soldiers assess the risk of completing a task, and policemen treat the notion of risk as a threat to a potential citizen. Ordinary employees often assess the risk of losing their jobs [own transl.]" (Skorupka, 2007, p. 33). It can be concluded that this fact determines the need to study the risk problem together with its detailed identification, especially in the field of railway investments, where risk management can be defined as a strategy whose main goal is to introduce a risk control strategy to the planning of a project.

Particular care should be taken when implementing a risk mitigation strategy to carefully plan a construction site. From the beginning, one should make sure that it is resistant to disturbances (Kowalski, Połoński \& Lendo-Siwicka, 2019). In the literature (Hastak, Lafayette, Univ, Halpin \& Wanegas, 1994; Linczowski \& Sobczyk, 1996; Woodward, 1997; Cleland \& Ireland, 2002), there are various approaches to the definition and process of scheduling. It is important that this process is based on reliable input data, especially in terms of potential identified risk factors. 
As it was written by Kowalski et al. (2019), traditional risk management methods are largely based on the experience and intuition of the people who use them. According to the authors, in a situation where railway projects are becoming more and more complex and the requirements of entities financing construction projects are constantly growing, this approach may lose its importance in the near future. When managing risk, the most reliable methods are those which base their methodologies on real databases, especially in terms of potential threats.

Due to the fact that it is still being looked for a relatively simple method of executive risk management which can be applied in construction practice, the authors present the most important assumptions of an original method of scheduling railway investments in the article. The developed method is called the railway matrix of risk factors - RMRF. Using this method, the likelihood of completion of an investment in terms of original timing and cost is assessed. Using the proposed method, the impact of identified risk factors on the implementation of a railway project can be assessed from the point of view of investors and contractors.

The risk assessment relates to the Design, the Build as well as the Design and Build contract types (scopes). The general assumption of the method is based on the correlation of the risks identified during the implementation of railway investments, previously identified by the authors on a national scale, with the specificity and conditions of the implementation of newly planned investments. A detailed description of the method is presented in Kowalski (2021). The proposed method is also, in a sense, a modular method, because it has been designed in such a way that it is possible to re-evaluate the system of risk factors (quantitatively, qualitatively) in the future, when it changes, and the developed scheme of the method remains unchanged. It should be emphasized that additional, newly identified risk factors can be included already in the current version of the method.

The presented method is a proprietary proposal for scheduling railway investments and, through a detailed correlation of risk with the relevant subtasks of the work breakdown structure - WBS (Project Management Institute [PMI], 2013), it will allow to determine the most likely possible completion dates and/ /or costs of individual stages of works and the entire construction project. The method does not interfere with the strategy of implementing contingency plans. The preparation of such plans and their implementation is left to the responsibility of the contractor's staff, contract engineer or investor.

\section{MATERIAL AND METHODS}

Having a list of potential identified risk factors, their quantitative analysis was performed. The obtained data were appropriately grouped into numerical sets and developed using appropriate statistical models available in the IBM SPSS Statistics 23 package (Kowalski et al., 2019). The results of these analyses are lists of risk factors which, according to the conducted research, most often have the greatest impact on the course of works on railway contracts in Poland. The lists of identified risk factors have been published, inter alia, in Kowalski and Połoński (2019).

In order to determine the weights of each threat, detailed calculations were made using the original equations being a part of the proposed method. The equations are described in detail in Kowalski (2021).

The most important indicator is the risk index $\left(W_{R i}^{r p}\right)$ - equations (1)-(4).

Weight assessment of the risk factor (risk index):

- for the Design stage:

$W_{R i}^{D D}=R_{i}^{D D} \cdot W D n_{i}^{D}$

$W_{R i}^{C D}=R_{i}^{C D} \cdot W C n_{i}^{D}$

- for the Build stage:

$W_{R i}^{D B}=R_{i}^{D B} \cdot W D n_{i}^{B}$

$W_{R i}^{C B}=R_{i}^{C B} \cdot W C n_{i}^{B}$

where:

$W_{R i}^{D D}, W_{R i}^{D B}$ - risk assessment index based on the weight for the $i$-th factor, affecting the duration of the investment both for the Design stage or the Build stage [\%], $W_{R i}^{C D}, W_{R i}^{C B}$ - risk assessment index based on the weight for the $i$-th factor, influencing the investment cost for both the Design stage or the Build stage [\%], 
$R_{i}^{D D}, R_{i}^{C D}, R_{i}^{D B}, R_{i}^{C B}$ - risk of the $i$-th factor for the Design or the Build stage affecting the investment time and cost [\%],

$W D_{n i}^{D}, W C_{n i}^{D}, W D_{n i}^{B}, W C_{n i}^{B}$ - normalized weight of the $i$-th risk factor affecting the investment duration (WD) or cost $(W C)$ for the Design $\left(n_{i}^{D}\right)$ or Build $\left(n_{i}^{B}\right)$ stage.

When implementing the proposed method in the real investment process, the risk index $\left(W_{R i}^{r p}\right)$ is determined automatically by completing the risk matrix (Fig. 1).

In order to facilitate the execution of the necessary calculations, a proprietary, special calculation sheet was developed in MS Excel program. Based on user-defined data, this calculation sheet calculates a percentage weighting index for the individual risk factors. When implementing the method with "underlying risk factors", the user is only required to specify the consequence of the impact of a given risk factor $(C)$, which should be entered in a specially defined field (risk matrix - Columns 11 and 12 in Fig. 1). The remaining elements were determined on the basis of the equations presented in Kowalski (2021). Due to the increased usability of the designed calculation sheet, it was decided to allow future users to define three other threats which were not identified at the calculation sheet creation stage. New threats can be added to the end of the existing list of risk factors. It is also necessary for the user to define their weights (Columns 6 and 7 in Fig. 1). It is recommended to define the weights in $\mathrm{min}$./max. intervals of the values of the underlying risk factors. It is sufficient to determine the value of the probability of occurrence labelled as $P$ (Column 10 in Fig. 1 - scale $0.0-1.0)$ and the consequences of the influence labelled as $C$ (Columns $11-12$ in Fig. 1 - scale $10-100 \%$ ).

After quantifying the risk factors, they are correlated with specific tasks in the process of implementing a construction project (Table 1). This is a step to be taken by the manager who plans a venture. Therefore,

\begin{tabular}{|c|c|c|c|c|c|c|c|c|c|c|c|c|c|c|c|}
\hline \multicolumn{16}{|c|}{ Rink Matrix_Desiza Stage } \\
\hline Na. & Factors of ideatified threats & $\begin{array}{l}\text { Ponition } \\
\text { MI }\end{array}$ & $\mathbf{M}$ & SD & $\begin{array}{l}\text { Woile of } \\
\text { the ith risk } \\
\text { factor } \\
\text { WDi }\end{array}$ & $\begin{array}{l}\text { Weidete of } \\
\text { thei-由 risk } \\
\text { factor } \\
\text { wCi }\end{array}$ & $\begin{array}{l}\text { Standurdeed } \\
\text { wciste } \\
\text { WDai }\end{array}$ & $\begin{array}{l}\text { Standradired } \\
\text { weile } \\
\text { WCai }\end{array}$ & $\begin{array}{c}\text { Probablitiny of } \\
\text { ccauresce } \\
\text { [schl } 0,0- \\
1,0] \\
\text { P }\end{array}$ & 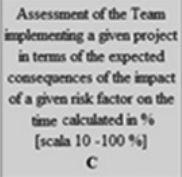 & 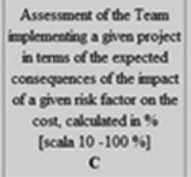 & $\begin{array}{l}\text { Risk } \\
\text { assessmet } \\
\text { [R] } \\
\text { [time] }\end{array}$ & $\begin{array}{c}\text { Risk } \\
\text { assessmetz } \\
{[R]} \\
{[\cos x]}\end{array}$ & 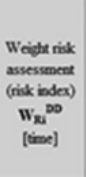 & 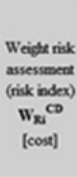 \\
\hline [1] & {$[2]$} & [3] & {$[A]$} & 15 & 16 & 17 & {$[5]$} & (9) & {$[10]$} & [II] & [12] & [13] & {$[14]$} & [15] & {$[16]$} \\
\hline 1 & $\begin{array}{l}\text { Procedtural defects in preparrabioe of tender } \\
\text { documets }\end{array}$ & 2 & 3902 & 3.185 & 2280 & 2.280 & 0.133 & 0.160 & 0.902 & $95 \%$ & $80 \% 6$ & 0.857 & 0.721 & $11.40 \%$ & $11.56 \%$ \\
\hline 2 & 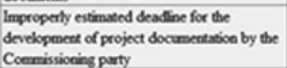 & 6 & 5.000 & 3.749 & 0.827 & 0.648 & 0.048 & 0.046 & 0.813 & $65 \%$ & $20 \% 6$ & 0.528 & 0.163 & $2.55 \%$ & 0.746 \\
\hline 3 & $\begin{array}{l}\text { To many enternal insthisices invohed in the } \\
\text { inveriomert process }\end{array}$ & 11 & 4348 & 2875 & 1.079 & 0.723 & 0.063 & 0.051 & 0.768 & $90 \%$ & 3066 & 0.691 & 0.230 & $435 \%$ & $1.17 \%$ \\
\hline 4 & 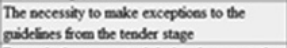 & 7 & 4.679 & 2.765 & 1384 & 1.333 & 0.081 & 0.094 & 0.866 & $90 \%$ & $30 \%$ & 0.779 & 0.433 & $6.30 \%$ & $4.06 \%$ \\
\hline 3 & $\begin{array}{l}\text { Erros in the cooceptual desion documentabion } \\
\text { froen the tender stage }\end{array}$ & 9 & 4,473 & 3.182 & 0.865 & 0.819 & 0.050 & 0.058 & 0.768 & $85 \%$ & $50 \%$ & 0.653 & 0.384 & $3.29 \%$ & $2.21 \%$ \\
\hline 6 & $\begin{array}{l}\text { Problems with obtaining curreat maps for } \\
\text { project pupposes froem ral geodesic certers }\end{array}$ & 1 & 6.482 & 3.277 & 2604 & 2232 & 0.152 & 0.157 & 0.893 & $100 \%$ & $100 \% 6$ & 0.893 & 0.893 & $13.57 \%$ & $14.01 \%$ \\
\hline 7 & 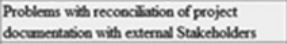 & 3 & 5,357 & 2860 & 1.962 & 1.472 & 0.115 & 0.103 & 0.857 & $95 \%$ & $30 \%$ & 0.814 & 0.429 & $9.33 \%$ & $4.43 \%$ \\
\hline 8 & 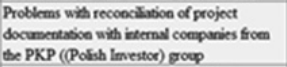 & 8 & 4.598 & 2,846 & 1,205 & 0.908 & 0.070 & 0.064 & 0.786 & $95 \%$ & $30 \%$ & 0.746 & 0.393 & $5.25 \%$ & $251 \%$ \\
\hline 9 & 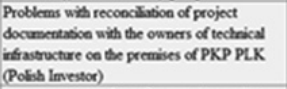 & 12 & 4.339 & 2.730 & 1.049 & 0.920 & 0.761 & 0.065 & 0.786 & $95 \%$ & $50 \%$ & 0.746 & 0.393 & $4.57 \%$ & $2.54 \%$ \\
\hline 10 & 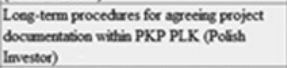 & 4 & 5.107 & 2960 & 1.610 & 1.054 & 0.094 & 0.024 & 0.768 & $85 \%$ & $60 \%$ & 0.653 & 0.461 & $614 \%$ & $3,41 \%$ \\
\hline 11 & 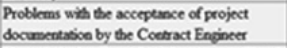 & 15 & 3205 & 2941 & 0.123 & 0.075 & 0.007 & 0.005 & 0.563 & $80 \%$ & $45 \%$ & 0.450 & 0.253 & $0.32 \%$ & $0.13 \%$ \\
\hline 12 & 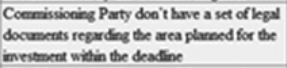 & 10 & 4.455 & 3.102 & 0.907 & 0.653 & 0.053 & 0.046 & 0.366 & $90 \% 6$ & $35 \%$ & 0.329 & 0.128 & 1.746 & $0.59 \%$ \\
\hline 13 & 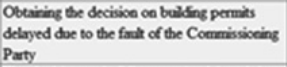 & 14 & 3.509 & 3.350 & 0.068 & 0.059 & 0.004 & 0.004 & 0.455 & $55 \%$ & $20 \%$ & 0.250 & 0.091 & $0.10 \%$ & 0.0496 \\
\hline 14 & $\begin{array}{l}\text { The decision co balling permits delayed doe } \\
\text { io the Desipper's fanit }\end{array}$ & 13 & 4.205 & 3.635 & 0.275 & 0.209 & 0.016 & 0.015 & $c .509$ & $50 \%$ & $20 \%$ & $c .254$ & 0.102 & $0.41 \%$ & $0.15 \%$ \\
\hline & 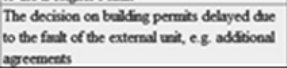 & 3 & 5.027 & 3.620 & 0.892 & 0.841 & 0.052 & 0.359 & 0.643 & $60 \%$ & $60 \% 6$ & 0.386 & C.386 & $201 \%$ & $2.28 \%$ \\
\hline
\end{tabular}

Fig. 1. Risk matrix. Design stage (own study) 
it is necessary to find which risk factor affects individual real tasks included in the base work schedule and its structure of the WBS (Table 2).

Table 1. Sample correlation of real tasks of the summary task X with risk factors (own study based on Skorupka, 2007)

\begin{tabular}{cc}
\hline Risk factor & Task name \\
\hline$a_{1}$ & $\mathrm{~A}, \mathrm{C}, \mathrm{H}$ \\
\hline$a_{2}$ & $\mathrm{C}, \mathrm{F}, \mathrm{G}$ \\
\hline$a_{3}$ & $\mathrm{~B}, \mathrm{C}, \mathrm{D}$ \\
\hline$a_{4}$ & $\mathrm{~A}, \mathrm{C}, \mathrm{E}$ \\
\hline$a_{5}$ & $\mathrm{C}, \mathrm{D}, \mathrm{E}$ \\
\hline$a_{6}$ & $\mathrm{D}, \mathrm{E}, \mathrm{F}, \mathrm{G}$ \\
\hline$a_{7}$ & $\mathrm{C}, \mathrm{D}$ \\
\hline$a_{8}$ & - \\
\hline$a_{9}$ & $\mathrm{H}, \mathrm{I}, \mathrm{B}$ \\
\hline
\end{tabular}

Then, for each actual activity, the most probable task completion time is calculated, taking into account the risk factors. The calculation is made according to the following formulas and the calculation process itself is performed automatically by the calculation sheet (risk matrices - subsequent tabs).

$$
\begin{aligned}
& T_{2, j}^{D}=T_{1, j}^{D}+\left(\sum_{j=1}^{Z} W_{R i}^{r p} \cdot T_{1, j}^{D}\right) \\
& T_{2, j}^{B}=T_{1, j}^{B}+\left(\sum_{j=1}^{Z} W_{R i}^{r p} \cdot T_{1, j}^{B}\right)
\end{aligned}
$$

where:

$T_{1, j}^{D}, T_{1, j}^{B}$ - planned completion time of the $j$-th task for the Design stage or the Build stage,

$T_{2, j}^{D}, T_{2, j}^{B}$ - the most probable duration of the $j$-th task for the Design stage or the Build stage, taking into account risk factors,

$W_{R i}^{r p}$ - weight risk assessment index for the $i$-th risk factor at the level of a construction project [\%],

$Z$ - number of risk factors.

As a consequence of the above actions, project teams will receive modified durations of all actual tasks, which, when applied to the previously created baseline plan, create an updated version of the schedule taking the risk into account. From the schedule prepared in this way, it will be very easy to read the calculated values of deviations from the base, original deadlines for individual real tasks, summary tasks or adopted milestones.

Table 2. Sample allocation of risk factors in the WBS structure of the schedule. Design stage (own study based on

\begin{tabular}{|c|c|c|c|c|c|c|c|c|c|c|c|c|}
\hline \multirow{2}{*}{ Task name } & \multicolumn{9}{|c|}{ Risk factor affecting individual tasks } & \multirow{2}{*}{$\sum W_{R i}^{D D}$} & \multirow{2}{*}{$\begin{array}{l}\mathrm{T}_{1} \\
\text { or } \\
\mathrm{K}_{1}\end{array}$} & \multirow{2}{*}{$\begin{array}{l}\mathrm{T}_{2} \\
\text { or } \\
\mathrm{K}_{2}\end{array}$} \\
\hline & $a_{1}$ & $a_{2}$ & $a_{3}$ & $a_{4}$ & $a_{5}$ & $a_{6}$ & $a_{7}$ & $a_{8}$ & $a_{9}$ & & & \\
\hline $\begin{array}{l}\text { Summary task } X \\
(\mathrm{Id}=1.1)\end{array}$ & $\mathrm{x}$ & $\mathrm{x}$ & $\mathrm{x}$ & $\mathrm{x}$ & $\mathrm{x}$ & $\mathrm{x}$ & $\mathrm{x}$ & & $\mathrm{x}$ & & & \\
\hline $\mathrm{Id}=2.1 .1 \mathrm{~A}$ & $W_{R i}^{D D}$ & & & $W_{R i}^{D D}$ & & & & & & & & \\
\hline $\mathrm{Id}=2.1 .2 \mathrm{~B}$ & & & $W_{R i}^{D D}$ & & & & & & $W_{R i}^{D D}$ & & & \\
\hline $\mathrm{Id}=2.1 .3 \mathrm{C}$ & $W_{R i}^{D D}$ & $W_{R i}^{D D}$ & $W_{R i}^{D D}$ & $W_{R i}^{D D}$ & $W_{R i}^{D D}$ & & $W_{R i}^{D D}$ & & & & & \\
\hline $\mathrm{Id}=2.1 .4 \mathrm{D}$ & & & $W_{R i}^{D D}$ & & $W_{R i}^{D D}$ & $W_{R i}^{D D}$ & $W_{R i}^{D D}$ & & & & & \\
\hline $\begin{array}{l}\text { Summary task X } \\
(\mathrm{Id}=1.2)\end{array}$ & $\mathrm{x}$ & $\mathrm{x}$ & & $\mathrm{x}$ & $\mathrm{x}$ & $x$ & $\mathrm{x}$ & & $\mathrm{x}$ & & & \\
\hline $\mathrm{Id}=2.1 .5 \mathrm{E}$ & & & & $W_{R i}^{D D}$ & $W_{R i}^{D D}$ & $W_{R i}^{D D}$ & & & & & & \\
\hline $\mathrm{Id}=2.1 .6 \mathrm{~F}$ & & $W_{R i}^{D D}$ & & & & $W_{R i}^{D D}$ & & & & & & \\
\hline $\mathrm{Id}=2.1 .7 \mathrm{G}$ & & $W_{R i}^{D D}$ & & & & $W_{R i}^{D D}$ & & & & & & \\
\hline $\mathrm{Id}=2.1 .7 \mathrm{H}$ & $W_{R i}^{D D}$ & & & & & & & & $W_{R i}^{D D}$ & & & \\
\hline \multicolumn{13}{|l|}{$\mathrm{Id}=2.1 .7 \mathrm{I}$} \\
\hline $\mathrm{Id}=2.1 .7 \mathrm{~J}$ & & & & & & & & & $W_{R i}^{D D}$ & & & \\
\hline
\end{tabular}
Skorupka, 2007)

$\sum W_{R i}^{D D}-$ potential \% increase of the original deadline for completing the task. 
Further calculations are presented on the example of task time, but the calculation procedure for costs is analogous. The results of exemplary analyses of the cost of implementation will be presented in later publications.

\section{RESULTS}

The aim of the authors was to present a method enabling a reliable estimation of the timing of a given investment project even before its commencement. The presented calculation example illustrates the importance of the problem in terms of planned implementation dates.

In accordance with the assumptions of the method, in the first step, the risk matrices were supplemented with regard to the consequences of the impact of individual risk factors on the tested object, and the risk factors were correlated with individual tasks in the WBS. Subsequently, after the transformation of the new durations to the MS Project program, a new investment duration was appointed along with deviations from the baseline (Fig. 2).
The example shows a small scope of the analyzed investment and the time exceeded over $30 \%$ in relation to the budget plan.

From the schedule prepared in this way, it is very easy to read the calculated values of deviations from the base, original deadlines, both for individual real tasks, summary tasks or adopted milestones.

\section{DISCUSSION}

The article deals with issues closely related to the scheduling (designing) of railway investments. The analyses genesis was the technical and economic problems of planning and implementing construction projects.

An example of calculating the probable project completion dates on the basis of the proposed method was presented on the example of the schedule for the construction of the E20 railway line - POIiŚ 7.1-9.1 project. The contract under study was implemented in accordance with the FIDIC Yellow Book procedures (Sørensen, 2019), so the contractor was responsible both for the preparation of design documentation and

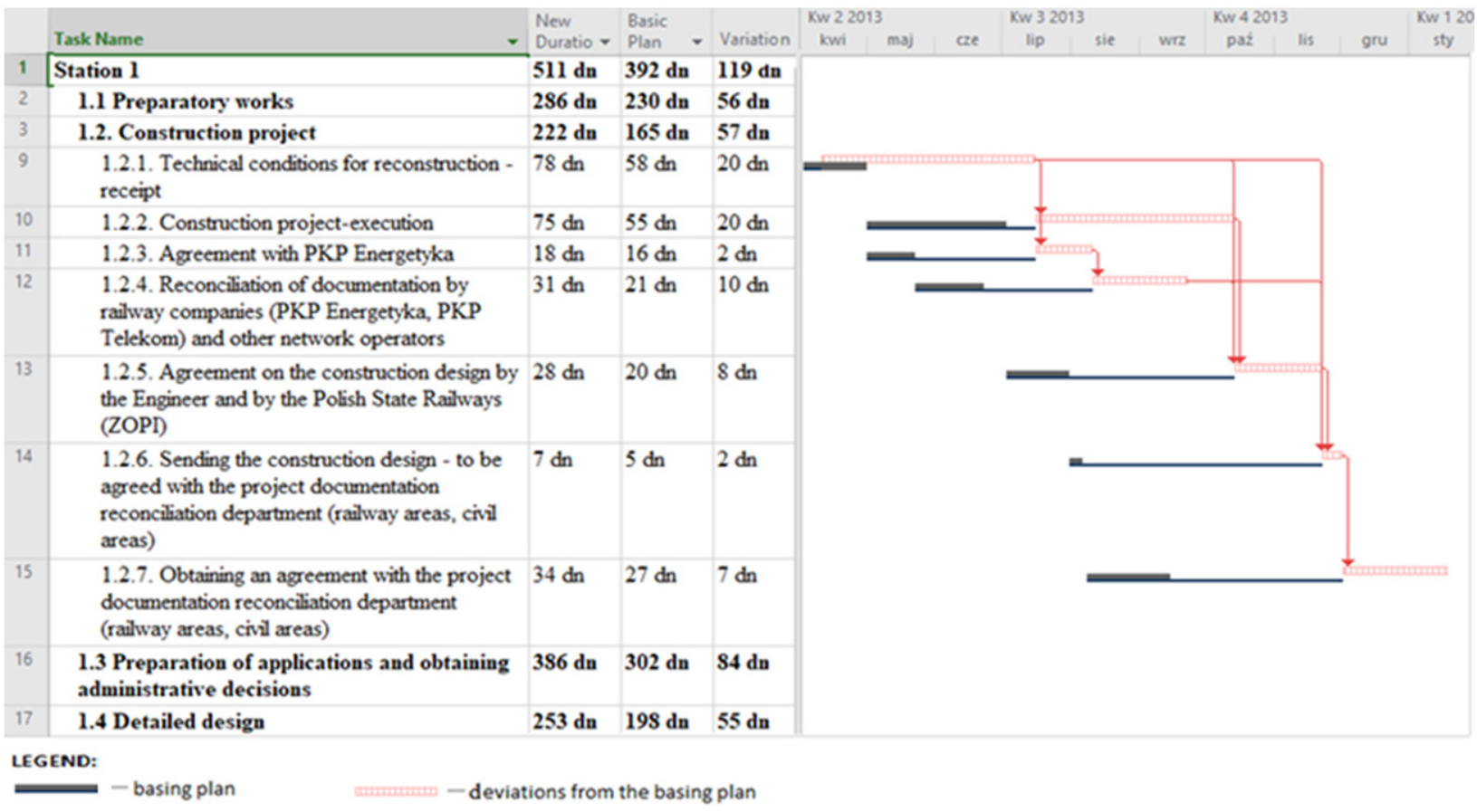

Fig. 2. Base plan and schedule update after taking into account the results of the risk analysis. Design stage (own study) 
the implementation of works. This method of contract implementation influenced its course as well as the responsibility and commitment of individual participants. The scope of works included the modernization of three railway stations and selected route sections between these stations on railway lines owned and operated by PKP Polskie Linie Kolejowe S.A.

As the entire detailed schedule included many tasks, the article presents an exemplary analysis of its fragment concerning the Design stage of the Railway Station 1 (within the scope of preparing a construction design).

\section{CONCLUSIONS}

The main conclusion resulting from the calculations can be formulated as follows: by setting new probable durations of $\mathrm{T}_{2}$ tasks, it is possible to build a schedule which, to some extent, takes potential threats into account, and thus increases the probability of meeting the deadline. Thanks to this, the user is able to plan his activities more precisely and to be better prepared for the implementation of the facility and meeting the planned budget.

An important element increasing the usefulness of the method is its ease of use. It was assumed that the easy-to-apply method would be more willingly implemented by teams planning Polish railway undertakings. The great advantage of the proposed method is that it can be used by all parties to the investment process.

\section{REFERENCES}

Anysz, H. (2017). Wykorzystanie sztucznych sieci neuronowych do oceny możliwości wystapienia opóźnień w realizacji kontraktów budowlanych [Delays in construction contracts execution. The evaluation of the possibility of their occurrence with the use of artificial neural networks] ( $\mathrm{PhD}$ thesis). Politechnika Warszawska, Warszawa.

Cleland, D. L. \& Ireland, L. R. (2002). Project Management. New York: McGraw-Hill Professional Publishing.
Hastak, M., Lafayette, W., Univ, P., Halpin, D. \& Wanegas, J. (1994). A Decision Support System for the Expansion of International Operations of A/E/C Firms. In K. Khozeimeh (Ed.), Computing in Civil Engineering: Proceedings of the First Congress Held in Conjunction with A/E/C Systems 94 (pp. 735-742). American Society of Civil Engineers.

Kowalski, J. (2021). Harmonogramowanie inwestycji kolejowych $w$ Polsce $z$ uwzględnieniem ryzyka $w$ trakcie ich realizacji [Scheduling railway investments in Poland, taking into account the risk during their implementation] (doctorial thesis). Szkoła Główna Gospodarstwa Wiejskiego w Warszawie, Warszawa.

Kowalski, J. \& Połoński, M. (2019). The method of planning the implementation of railway investments including risk. Archives of Civil Engineering, 65 (3), 45-59.

Kowalski, J., Połoński, M. \& Lendo-Siwicka, M. (2019). Risk factors for delays in rail investments implemented in the Design \& Build contracts. MATEC Web of Conferences, 262, 07007. https://doi.org/10.1051/matecconf/201926207007

Linczowski, C. \& Sobczyk, Z. (1996). Organizacja i planowanie w budownictwie. Częstochowa: Wydawnictwo Politechniki Częstochowskiej.

Pfeffer, I. (1956). Insurance and Economic Theory. Chicago: Homewood.

Połoński, M. (2015). Application of the work breakdown structure in determining cost buffers in construction schedules. Archives of Civil Engineering, 61 (1), 147-161 .

Project Management Institute [PMI] (2013). A guide to the Project Management Body of Knowledge (PMBOK® guide). Project Management Institute.

Regan, S. T. (2003). Risk Management Implementation and Analysis. International Transaction (CSC.10.1-CSC.10.7). Association for the Advancement of Cost Engineering International.

Skorupka, D. (2007). Metoda oceny ryzyka budowlanego (habilitation dissertation). Wojskowa Akademia Techniczna, Warszawa.

Sørensen, J. B. (2019). FIDIC Yellow Book: A companion to the 2017 Plant \& Design Build Contract. London: ICE Publishing.

Willett, H. W. (1951). The Economic Theory of Risk Insurance. Philadelphia: University of Pensylwania Press.

Woodward, J. F. (1997). Construction Project Management. London: Thomas Telford. 


\section{MATRYCA CZYNNIKÓW RYZYKA DLA PROJEKTÓW KOLEJOWYCH}

\section{STRESZCZENIE}

W artykule przedstawiono główne założenia oryginalnej metody do harmonogramowania inwestycji kolejowych w Polsce z uwzględnieniem czynników ryzyka w trakcie ich realizacji. Czynniki ryzyka zostały zidentyfikowane przez autorów w trakcie szeroko zakrojonych badań i analiz. Na podstawie proponowanej metody przyszły użytkownik będzie mógł wyznaczyć najbardziej prawdopodobny koszt oraz szacunkowy czas trwania planowanej inwestycji. W artykule przedstawiono również implementację metody w rzeczywistym procesie inwestycyjnym w zakresie czasu jej realizacji. Podczas projektowania metody przyjęto założenie, że nieskomplikowana we wdrożeniu i wsparta odpowiednim programem obliczeniowym metoda zmotywuje zespoły planujące realizację przedsięwzięć kolejowych do jej implementacji w rzeczywistych procesach realizacyjnych i zwiększy wiarygodność opracowywanych przez nie harmonogramów.

Słowa kluczowe: identyfikacja zagrożeń, ryzyko, inwestycje kolejowe, planowanie robót budowlanych, macierz ryzyka 